\title{
The Perception of the Muslims in Malaysia on the Belief of Afterlife
}

\author{
Mohd Arip Kasmo ${ }^{2}$, Abur Hamdi Usman ${ }^{1}$, Fazilah Idris ${ }^{2}$, Aminuddin Basir ${ }^{2}$, Nasruddin Yunos ${ }^{2}$, Siti Nur Baya \\ Mat Yacob ${ }^{2}$, Nik Yusri Musa ${ }^{2} \&$ Khalim Zainal ${ }^{2}$ \\ ${ }^{1}$ Institute of Islam Hadhari, The National University of Malaysia, Malaysia \\ ${ }^{2}$ Centre for General Studies, The National University of Malaysia, Malaysia \\ Correspondence: Abur Hamdi Usman, Institute of Islam Hadhari, The National University of Malaysia, 43600, \\ Bangi, Selangor, Malaysia. Tel: 60-16-690-5082. E-mail: aburhamdiusman@yahoo.com
}

Received: January 29, 2014 Accepted: February 23, 2015 Online Published: May 15, 2015

doi:10.5539/ass.v11n15p49 URL: http://dx.doi.org/10.5539/ass.v11n15p49

\begin{abstract}
The belief of Afterlife is one of the fundamental of Islamic belief system. The wellbeing in this world will reflect our future in the Hereafter. Knowing the level of Muslim's perception on the Afterlife could illustrate that the Malaysian Muslims are still upholding the Islamic teachings and traditions. This paper reports on the findings of a study on Malaysian's Muslims perception towards the metaphysical dimension of the Islamic belief system, specifically the Afterlife. 640 respondents, males and females (aged 18 to 55 years old) participated in the study. They were randomly selected from all over Malaysia and were given a booklet of questionnaire, containing statements about the Islamic belief system including the belief in the Afterlife. Each statement was provided with five choices in the form of Likert type scale ranging from 1 to 5 . The booklets of questionnaire were collected and the responses were analysed using Statistical Package for the Social Sciences (SPSS) to obtain the means responses and also the percentages of the responses. The means differences were tested using the t-test also one-way ANOVA. The study discovered that Malaysian $99.4 \%$ of the respondents believed the afterlife. Only $0.6 \%$ of the respondents either not sure or did not believe the afterlife.
\end{abstract}

Keywords: belief, Muslim, Malaysia, afterlife

\section{Introduction}

Like any other religions, Islam does have the belief in afterlife. The belief in afterlife and also other aspect of the religious belief have been weakening in all major religions such as Christianity and Judaism especially in the more advance countries in Europe, North America, Australia and New Zealand (Fulcher \& Scott, 2011).

The British Broadcasting Corporation in its report, under the title The Vicars Who Do Not Believe in God reported that many vicars and priests did not believe in the existence of god (Note 1). David Jenkins, the former bishop of Durham for example was one of the vicars who did not believe the physical resurrection of Jesus and the virgin birth. According to the news portal, a group known as Sea of Faith claimed to have up to 50 vicars and some Roman Catholic priests claimed that they did not believe in the existence of god. The phenomenon may be pertinent to Christianity in the west because the western society is very much influenced by empiricism, the philosophy which claims that any knowledge which is not derived from science is unreliable (Dixon, 1999).

The study was therefore conducted to see whether the Muslims in Malaysia are also facing the same issue as the Christians and the Jews in the West do. The study on the belief of afterlife among the Muslims is important in order to measure the progresses of science in Malaysia. Does the progress in science have any effect on the belief of the Muslims toward their religion especially in the belief in afterlife? The study is important because in the Muslim community, belief in the afterlife formed the basis of the morality. The finding of the study can be used by the authority in the field of the Islamic education to plan the education curriculum and the academicians all around the world in the pursuit of understanding the psychology of the practising Muslims.

\section{Belief in Afterlife: A Briefly Overview}

The study aims to know whether the Muslims in Malaysia are still maintaining a strong belief in the afterlife. Belief in afterlife is central to the Islam itself because disbelief in this is considered to be blasphemous and negate the religion. Among the other Islamic beliefs is the belief in the Unseen, Predestination, the Hereafter, Hell and Heaven, Reward and Punishment (Abu Zahrah, 2002). Muslims today tend to be more firmly rooted in 
their religious beliefs than the Western Christians and the Jews, and the belief in the afterlife is ever present and ever urgent reality (Walls, 2007). In a study which was conducted by Hassan (2008), more than $90 \%$ of the Indonesian, Pakistani, Malaysian and Egyptian completely believe in the life after death. The percentage were lower among Iranian with $84 \%$ believe in life after death, the Turk with $71 \%$ believe in life after death and only $13 \%$ of the Kazaks believe in the life after death. The study by Hassan (2008) shows that the belief in afterlife is strong within the Muslim community, except where communism had ruled before such as in Kazakhstan.

In Judaism, afterlife is also an important eschatological concept which was present in the pre-modern Jewish belief. However, the modern Judaism has now lost touch with the whole motion of life after death (Raphael, 2009). Most of the American Christians of all denominations continue to assent to a belief in resurrection but closer scrutiny shows that many do not believe that the physical body will be resurrected (Bartalos, 2008). The concept of afterlife which is found in three Abrahamic faiths, namely Islam, Christianity and Judaism are important basis for the good and virtuous life. Death is depicted as settling accounts in which the action of one's life would be evaluated and one would be punished or rewarded accordingly (Baumeister, 1991)

The Muslims of South East Asia are among the most devoted Muslim in the world (Rane, 2014). According the Wall Strait Journal, research conducted by Pew Research Centre which study the values, rituals and life styles of 35,000 people around the world, including 5,000 respondents in Indonesia, Malaysia and Thailand, 98\% of Indonesian, $93 \%$ of the Malaysian and $90 \%$ of Thai Muslims pay the zakah which is the third pillar of Islam. Moreover, $99 \%$ of Malaysian and Indonesian in the survey said they fasted during the month of Ramadan, and all the Thai Muslim said they fasted in the month of Ramadhan. In addition, $72 \%$ of the Indonesian attended the mosques at least once a week, $57 \%$ in Malaysia, $61 \%$ in Egypt and $44 \%$ in Turkey. The main factor that encouraged the Muslims to practice the Islamic teaching is none other than the belief in the Islamic eschatology such as reward and punishment, hell and heaven (Prieto, 2014).

The stronger the belief in afterlife, the more obedient they are (Penguin, 2010). However, this belief cannot be proven and as such it is quite difficult for the people to fully believe and convinced with them. The strength of belief in religion in the western religion i.e. Christianity has been the subject of the book written by Wuthnow (1988) who argued that in the seventies of the twentieth century, belief among college students had declined more dramatically than the less educated people. The belief in afterlife had also been the main issues debated by the ancient Islamic scholars of the Mutazilites and the Asharites, which among other debated whether the soul perished or not when a person died, whether the world was temporary or everlasting. Another issue which was debated between the two schools of thoughts was whether the Qur'an was the God's word or the created being (Naseem, 2001).

\section{Analysis and Methodology}

The study was conducted among 640 respondents obtained randomly from all over Malaysia ranging from the age of 18 to 55 years old. The respondents came from different parts of the country. Each respondent was given a booklet of questionnaire with statements about the metaphysical dimension of the Islamic teaching.

There were two parts of the questionnaire i.e. the first was the biography of the respondents which formed the independent variable. The independent variables include the age, gender, academic qualification, education backgrounds such as religious education or non-religious background, marital status etc. The second part was the dependent variables containing various statements on Islamic eschatology such as the belief in the existence of god, predestination, hell and heaven, reward and punishment.

Each statement was accompanied with five choices of responses in the form of Likert style scale ranging from 1 (strongly agreed), 2. (Agreed), 3. (Not sure), 4. (Disagreed), and 5. (Strongly disagreed). The respondents were given between 15 to 20 minutes to respond to the questionnaire. The booklets were collected and the data were analysed using the SPSS software. The data were analysed to obtain the descriptive statistics i.e. percentages and means as well as inferences statistics such as the significance differences.

Likert style scale was used in this study because it measures attitude of the respondents. Kothari (2011) listed five reasons why Likert scale is a good instrument of test. The five reasons are: First, it is relatively easy to construct. Second, it is more reliable instrument because respondents answer each statement included in the instrument. Third, each statement included in the Likert scale is given an empirical test for discriminating ability. Fourth, Likert scale can easily be used. Fifth, it takes less time to construct. The responses were analysed using the Statistical Package for the Social Sciences (SPSS), to find the percentages, the means, the correlation and the difference of means. The statement which were analysed for this paper are "I believe in the Hell and the Heaven" and "I believe in the existence of the hereafter." 


\subsection{Data Analysis}

The education level of the respondents is one of the important variable in the study because it can be used to know whether the education level influence the belief in hereafter. The result of the analysis is shown in Table 1.

Table 1. The education level of the respondents

\begin{tabular}{lllll}
\hline & Frequency & Percent & Valid Percent & Cumulative Percent \\
\hline Primary education & 10 & 1.4 & 1.5 & 1.5 \\
Lower School Cert & 93 & 13.2 & 13.6 & 15.0 \\
O-Level & 173 & 24.5 & 25.3 & 40.3 \\
A-Level/Diploma & 117 & 16.6 & 17.1 & 57.4 \\
Bachelor & 268 & 38.0 & 39.1 & 96.5 \\
Master/ PhD & 24 & 3.4 & 3.5 & 100.0 \\
\hline Total & 685 & 97.0 & 100.0 & \\
\hline
\end{tabular}

Table 1 shows the number of respondents and the percentages of the respondents. The percentages of the respondents are presented in the form of bar chart as shown in Diagram 1.

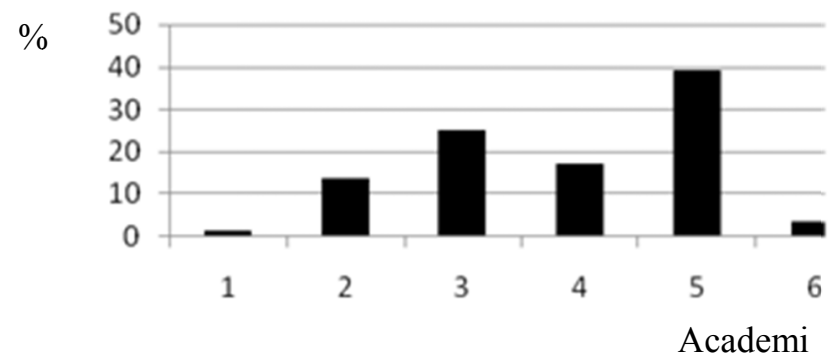

Diagram 1. Bar chart the percentages of the respondents

Education background. 1. Primary education, 2. PMR/LCE, 3. SPM/O-Level, 4. Diploma/STPM, 5. Bachelor, 6. Master $/ \mathrm{PhD}$.

\section{Belief in the Existence of Heaven and Hell}

The response to the statement "I believe in the existence of the Heaven and Hell" was analysed to obtain the means and percentage of the responses. The result of the analysis is shown in Table 2.

Table 2. The mean for the response "I believe in the existence of the hell and the heaven"

\begin{tabular}{ccccc}
\hline $\mathrm{N}$ & Minimum & Maximum & Mean & Std. Deviation \\
\hline 674 & 1.00 & 5.00 & 1.0608 & .30959 \\
\hline
\end{tabular}

Table 2 shows that the mean response is 1.0608 . The means indicate that the respondents strongly agreed to the statement. The mean can be interpreted that the respondents strongly believe in the existence of the hell and the heaven. Moreover, the next analysis is to obtain the percentage of each response. The result of the analysis is shown in Table 3.

Table 3. The percentage of the response to the statement "I believe in the existence of the Heaven and Hell"

\begin{tabular}{ccccc}
\hline & Frequency & Percent & Valid Percent & Cumulative Percent \\
\hline Strongly agreed & 637 & 94.2 & 94.2 & 94.2 \\
Agreed & 35 & 5.2 & 5.2 & 99.4 \\
Not sure & 1 & .1 & .1 & 99.6 \\
Disagreed & 1 & .1 & .1 & 99.7 \\
Strongly disagreed & 2 & .3 & .3 & 100.0 \\
\hline
\end{tabular}

Table 3 shows that the percentages of the responses are $94.2 \%$ strongly agreed, $5.2 \%$ agreed, $0.1 \%$ not sure, $0.1 \%$ disagreed and $0.2 \%$ strongly disagreed. The result shows that $99.4 \%$ of the respondents accepted the statement. Only $0.4 \%$ did not accept the statement while $0.1 \%$ was not sure. 
The next analysis is to obtain the mean response according to the age group of the respondents. The result of the analysis is shown in Table 4.

Table 4. The mean responses according to the age group

\begin{tabular}{cccc}
\hline Age & Mean & $\mathrm{N}$ & Std. Deviation \\
\hline$<15$ & 1.0000 & 5 & .00000 \\
$16-20$ & 1.0203 & 148 & .18330 \\
$21-25$ & 1.0876 & 194 & .28349 \\
$26-30$ & 1.0556 & 54 & .23121 \\
$31-40$ & 1.0385 & 52 & .19418 \\
$40-50$ & 1.0545 & 55 & .22918 \\
$>51$ & 1.0263 & 38 & .16222 \\
\hline
\end{tabular}

Table 4 shows the mean responses o to the statement "I believe in the existence of the Hell and the Heaven". There seems to be different of means and the difference of mean was tested using one way ANOVA. The result of the analysis is shown in Table 5.

Table 5. One way ANOVA analysis according to the age of the respondents

\begin{tabular}{llllll}
\hline & Sum of Squares & Df & Mean Square & F & Sig. \\
\hline Between Groups & .447 & 7 & .064 & 1.185 & .309 \\
Within Groups & 29.016 & 539 & .054 & & \\
\hline Total & 29.463 & 546 & & & \\
\hline
\end{tabular}

Table 5 shows that the $\mathrm{p}$ value is 0.309 and the value is greater than the critical value of 0.05 . This indicates that the difference of mean between the respondents based on their age groups is not significant.

The next analysis is to obtain the mean response according to the education level of the respondents. The result of the analysis is shown in Table 6.

Table 6. The means response based on the education level of the respondents.

\begin{tabular}{cccc}
\hline Education level & Mean & $\mathrm{N}$ & Std. Deviation \\
\hline Primary & 1.0000 & 10 & .00000 \\
Lower Certificate of Education & 1.0238 & 84 & .21822 \\
O level & 1.0429 & 163 & .20336 \\
A-Level/Diploma & 1.0439 & 114 & .20569 \\
Bachelor & 1.0996 & 261 & .42702 \\
Post graduate & 1.0435 & 23 & .20851 \\
\hline
\end{tabular}

Table 6 shows that there were very small differences of the mean responses of the respondents according to their education level. The mean differences are tested using the one-way ANOVA to find out if the mean differences are significant, or not. The result of the test is shown in Table 7.

Table 7. One-way ANOVA test according to the education level

\begin{tabular}{cccccc}
\hline & Sum of Squares & Df & Mean Square & F & Sig. \\
\hline Between Groups & .635 & 5 & .127 & 1.291 & .266 \\
Within Groups & 63.799 & 649 & .098 & & \\
\hline Total & 64.434 & 654 & & & \\
\hline
\end{tabular}

Table 7 shows that the $\mathrm{p}$ value is 0.266 which is bigger than the critical value of 0.05 . This means that the mean difference between the respondents based on the education level of the respondents are not significant.

The next statement which analysed was "I am convinced with the existence of the Hereafter". The responses were analysed to obtain the mean response to the statement. The result of the analysis is shown in Table 8. 
Table 8 . The mean response to the statement "I believe in the existence of the Hereafter"

\begin{tabular}{ccccc}
\hline $\mathrm{N}$ & Minimum & Maximum & Mean & Std. Deviation \\
\hline 677 & 1.00 & 5.00 & 1.1196 & .41657 \\
\hline
\end{tabular}

Table 8 shows that the mean response for all the respondents to the statement "I am convinced with the existence of the Hereafter" is 1.1196 . The mean is very close to 1 which indicates that the respondents strongly agreed to the statement.

The next analysis was to obtain the percentage of the response to the statement. The result of the analysis is shown in Table 9.

Table 9. Percentage of the response

\begin{tabular}{|c|c|c|c|c|}
\hline & Frequency & Percent & Valid Percent & Cumulative Percent \\
\hline Strongly agreed & 612 & 86.7 & 90.4 & 90.4 \\
\hline Agreed & 54 & 7.6 & 8.0 & 98.4 \\
\hline Not sure & 8 & 1.1 & 1.2 & 99.6 \\
\hline Disagreed & 1 & .1 & .1 & 99.7 \\
\hline Strongly disagreed & 2 & .3 & .3 & 100.0 \\
\hline Total & 677 & 95.9 & 100.0 & \\
\hline
\end{tabular}

Table 9 shows the percentages of the responses for the statement "I am convinced with the existence of the Hereafter". $86.7 \%$ of the respondents strongly agreed to the statement, $7.6 \%$ agreed, $1.1 \%$ were not sure, $0.1 \%$ disagreed and $0.3 \%$ strongly disagreed. Therefore, $94.3 \%$ of the respondents accepted the statement. Hence, to show the close link between the belief in the existence of the hell and the heaven and the belief in the existence of the hereafter, the percentage responses to both statements were plotted into line graph as shown in Diagram 2.

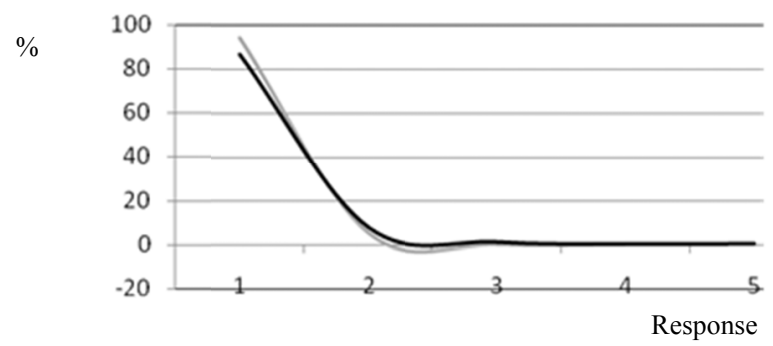

Diagram 2. The curve graph of the percentages of responses

Diagram 2 shows that there is not much difference between the strength of belief and to the existence of the hereafter among the respondents. The mean between the responses to the statement "I am convinced with the existence of the Hell and Heaven" is compared to the mean of the response to the statement "I am convinced with the existence of the Hereafter" The result of the t-test is shown in Table 10.

Table 10. T-test between the mean responses of both statements

\begin{tabular}{|c|c|c|c|c|c|c|}
\hline \multicolumn{5}{|c|}{ Paired Differences } & \multicolumn{2}{|c|}{$\mathrm{t} \quad \mathrm{df}$ Sig. (2-tailed) } \\
\hline \multirow{2}{*}{ Mean } & \multirow{2}{*}{ Std. Deviation } & \multirow{2}{*}{ Std. Error Mean } & \multicolumn{2}{|c|}{ 95\% Confidence Interval of the Difference } & & \\
\hline & & & Lower & Upper & & \\
\hline-.05812 & .31560 & .01218 & -.08204 & -.03420 & -4.771670 & .000 \\
\hline
\end{tabular}

Table 10 shows that the $\mathrm{p}$ value is 0.000 and the value is smaller than the critical value of 0.05 . This means that the mean difference is significant. The significance difference does not imply disbelief because the means still within the range of acceptance of the responses lies between the responses of strongly agreed and agreed.

\section{Discussion}

The study indicates two important findings. The respondents have strong belief in the Existence of Hell and Hereafter. The percentage of the respondents who accepted the statement is $99.4 \%$ (see Table 3 ). This finding is close to the finding of Hassan (2008). The percentage of the respondents who did not accept the statement was very small. Only about $0.4 \%$ did not accept the statements and $1.1 \%$ of the respondents were not sure. Similarly 
the belief on the existence of hereafter was very high. The percentage of the respondents who accept the statements "I am convinced with the existence of Hereafter" is $98.4 \%$ (combination of response 4 and 5 , please-see table 9). The significant difference of mean between the responses to the statement "I believe in the existence of the Hell and the Heaven" and the mean difference between the responses to the statement "I believe in the existence of the Hereafter" has no negative implication since both are related to each other.

The findings seem to support the research which was conducted by the Pew Research Centre (Note 2) which says that the Muslims in Southeast Asia area among the most devoted to their religion. The analyses conducted show that there were no differences in the strength of the belief among those respondents of different age groups as well as those who have different education level. The education levels of the Muslims do not influence their belief in the afterlife (See Table 7). Although the percentage of the respondents who accepted the statements was high, what is to be highlighted here is the percentage of the respondents who rejected the statement. Those who rejected the statement represent $0.4 \%$ of the respondents. Taking into account the sample was randomly selected, it represent the general population of Muslims in Malaysia which is about $60 \%$ of the total population (Saravanan, 2009), i.e. 18,000,000 people.

Therefore, the numbers of people who are not convince to the existence of the Hell and the Heaven, and the existence of the Hereafter is estimated for about 72,000 people. The percentage of the respondents who were not sure was $1.2 \%$ that represents 216,000 people. The finding of the study thus has confirmed the past studies which says that the Muslim have strong belief in their religion (Samovar et al., 2012).

\section{References}

Abu Zahrah, M. (2002). The Islamic Creed: According to the Glorious Qur'an. Damascus: Dar al-Kalima.

Bartalos, M. K. (2008). Speaking of Death: America's New Sense of Mortality: America's New Sense of Mortality. Westport: Greenwood Publishing Group.

Baumeister, R. F. (1991). Meanings of Life. New York: Guilford Press.

Dixon, N. M. (1999). The Organizational Learning Cycle: How We Can Learn Collectively.

Fulcher, J., \& Scott, J. (2011). Sociology. Oxford: Oxford University Press.

Hassan, R. (2008). Inside Muslim Minds. Melbourne: Melbourne University Publishing.

Naseem, H. (2001). Muslim Philosophy: Science and Mysticism. New Delhi: Sarup \& Sons.

Neurath, O. (1973). Empiricism and Sociology. Holland: Springer Science \& Business Media. http://dx.doi.org/10.1007/978-94-010-2525-6

Prieto, C. K. (2014). Religion and Spirituality across Cultures. New Jersey: Springer. http://dx.doi.org/10.1007/978-94-017-8950-9

Rane, H. (2014). Media Framing of the Muslim World: Conflicts, Crises and Contexts. New York: Palgrave Macmillan. http://dx.doi.org/10.1057/9781137334831

Raphael, S. P. (2009). Jewish views of the afterlife. New York: Maryland Rowman \& Littlefield.

Samovar, L. A. (2012). Communication between Cultures. Boston: Cengage Learning.

Saravanan, J. (2009). Islam and Politics in Southeast Asia. New York: Routledge.

Walls, J. L (2007). The Oxford Handbook of Eschatology. United Kingdom: Oxford University Press. http://dx.doi.org/10.1093/oxfordhb/9780195170498.001.0001

Wuthnow, R. (1988). The Restructuring of American Religion: Society and Faith Since World War II. Princeton, New Jersey: Princeton University Press.

\section{Notes}

Note 1. See http://news.bbc.co.uk/2/hi/uk_news/393479.stm

Note 2. See http://www.pewresearch.org/fact-tank/2013/07/09/global-median-of-93-of-muslims-say-they-fastduring-ramadan/

\section{Copyrights}

Copyright for this article is retained by the author(s), with first publication rights granted to the journal.

This is an open-access article distributed under the terms and conditions of the Creative Commons Attribution license (http://creativecommons.org/licenses/by/3.0/). 